Agnieszka Kościańska

Uniwersytet Warszawski

\title{
Panika wokół gender - temat zastępczy czy spór o obywatelstwo kulturowe ${ }^{1}$
}

29 grudnia 2013 roku, czyli w dzień, kiedy katolicy obchodzą Niedzielę Rodziny Świętej, w polskich kościołach odczytano list przygotowany na tę okazję przez biskupów. Pasterze polskiego Kościoła katolickiego, jak mówią o sobie biskupi, zaczęli od przywołania słów papieża Polaka:

Błogosławiony Jan Paweł II (...) przypomina, że prawda o instytucji małżeństwa jest „ponad wolą jednostek, kaprysami poszczególnych małżeństw, decyzjami organizmów społecznych i rządowych” (...). Prawdy tej należy szukać u Boga, ponieważ „sam Bóg jest twórcą małżeństwa" (...). To Bóg stworzył człowieka mężczyzną i kobietą, zaś bycie - w ciele i duszy - mężczyzną "dla" kobiety i kobietą „dla” mężczyzny uczynił wielkim i niezastąpionym darem oraz zadaniem w życiu małżeńskim. Rodzinę oparł na fundamencie małżeństwa złączonego na całe życie miłością nierozerwalną i wyłączną. Postanowił, że taka właśnie rodzina będzie właściwym środowiskiem rozwoju dzieci, którym przekaże życie oraz zapewni rozwój materialny i duchowy (Episkopat 2013).

Następnie biskupi podkreślają, że chrześcijańskie rozumienie małżeństwa pochodzi z natury i należy je chronić. Tu nasuwa się pytanie: Czy w kraju, gdzie zdecydowana większość obywateli identyfikuje się z katolicyzmem, małżeństwo rozumiane jako związek kobiety i mężczyzny znajduje się pod specjalną,

1 Wpływ na kształtowanie się idei zaprezentowanych w tym artykule miały: dyskusja panelowa pt. Rewolucja seksualna - była, jest czy będzie?, która odbyła się w ramach Festiwalu Równe Prawa do Miłości (Warszawa, 10.02.2014) - serdecznie dziękuję Agnieszce Weseli za zaproszenie i inspirującą rozmowę; praca nad wykładem Seksualność w PRL i dziś. Temat zastępczy czy spór o obywatelstwo kulturowe? wygłoszonym na Ogólnopolskiej Interdyscyplinarnej Konferencji Naukowej „Seksualność, męskość, edukacja. Panika moralna 2013/2014 - rekonstrukcje" (Wydział Nauk Społecznych Uniwersytetu Gdańskiego, 15-16.10.2014) - jestem ogromnie wdzięczna prof. Lucynie Kopciewicz za zaproszenie i zachętę; artykuł Who Can be a True Pole? On Gender Panic, który ukazał się w "V4 Revue" (http://visegradrevue.eu/?p=2934) - dziękuję Partycji Bukalskiej z redakcji „V4 Revue” za mobilizację do pracy i Michałowi Petrykowi za pomoc w spolszczeniu zaprezentowanych tam myśli. I w końcu nie napisałabym tego tekstu, gdyby nie trwające od lat rozmowy z prof. Hadleyem Renkinem z CEU, badaczem homofobii na Węgrzech. 
konstytucyjną ochroną ${ }^{2}$, a związek zawarty w kościele - dzięki konkordatowi - ma wagę ślubu państwowego, takie małżeństwo jest zagrożone? Według pasterzy tak; tę wizję niszczą „zwolennicy ideologii gender".

"Ideologia gender" to termin, który pojawił się w polskich mediach latem 2013 roku i szybko stał się tematem wypowiedzi najpierw księży katolickich i świeckich katolickich dziennikarzy, a następnie feministycznych uczonych, którzy/e usiłowali/ły wyjaśnić, że gender nie jest ideologią, tylko terminem analitycznym bardzo pomocnym w zrozumieniu kulturowych i społecznych źródeł dyskryminacji kobiet, przemocy domowej, a także męskich i żeńskich ról społecznych oraz tożsamości płciowych. Po kilku miesiącach wszyscy dyskutowali o gender, niespodziewanie ten naukowy termin stał się głównym tematem polskiej debaty publicznej. List pasterski pojawił się w momencie, gdy spór stał się naprawdę gorący. Biskupi postanowili wyjaśnić, o co chodzi i bronić wartości katolickich:

Wobec nasilających się ataków tej ideologii skierowanych na różne obszary życia rodzinnego i społecznego czujemy się przynagleni, by z jednej strony stanowczo i jednoznacznie wypowiedzieć się $\mathrm{w}$ obronie chrześcijańskiej rodziny, fundamentalnych wartości, które ją chronią, a z drugiej przestrzec przed zagrożeniami płynącymi z propagowania nowego typu form życia rodzinnego (Episkopat 2013).

Pasterze zaczynają więc od definicji „,ideologii gender”. Według nich:

stanowi efekt trwających od dziesięcioleci przemian ideowo-kulturowych, mocno zakorzenionych $\mathrm{w}$ marksizmie i neomarksizmie, promowanych przez niektóre ruchy feministyczne oraz rewolucję seksualną. Genderyzm promuje zasady całkowicie sprzeczne z rzeczywistością i integralnym pojmowaniem natury człowieka. Twierdzi, że płeć biologiczna nie ma znaczenia społecznego, i że liczy się przede wszystkim płeć kulturowa, którą człowiek może swobodnie modelować i definiować, niezależnie od uwarunkowań biologicznych. Według tej ideologii człowiek może siebie w dobrowolny sposób określać: czy jest mężczyzną czy kobietą, może też dowolnie wybierać własną orientację seksualną. To dobrowolne samookreślenie, które nie musi być czymś jednorazowym, ma prowadzić do tego, by społeczeństwo zaakceptowało prawo do zakładania nowego typu rodzin, na przykład zbudowanych na związkach o charakterze homoseksualnym (Episkopat 2013).

Warto tu podkreślić, że biskupi, podobnie jak inni krytycy gender, definiują ten termin niezwykle szeroko - to nie tylko kształtowana społecznie rola płciowa, lecz także homo- $\mathrm{i}$ transseksualność, a wszystkie te kategorie traktowane są jako płynne i łatwo zmienne na poziomie indywidualnym. Na próżno szukać w lekturach feministycznych czy queerowych takiego szerokiego i woluntarystycznego ujęcia ${ }^{3}$.

2 „Małżeństwo jako związek kobiety i mężczyzny, rodzina, macierzyństwo i rodzicielstwo znajdują się pod ochroną i opieką Rzeczypospolitej Polskiej", art. 18 Konstytucji Rzeczypospolitej Polskiej z dnia 2 kwietnia 1997 roku.

3 Polemika z biskupią definicją terminu gender wykracza poza ramy tego artykułu. Jednak tego typu krytyka pojęcia gender pojawiała się niejednokrotnie, a już wiele lat temu rozprawiała się z nią Carole Vance (2007, s. 15-31). 
Wróćmy jednak do listu. Następnie autorzy przechodzą do niebezpieczeństwa związanego z ideologią gender. Według biskupów jest ona destrukcyjna zarówno dla jednostki, jak i całego społeczeństwa:

Człowiek o niepewnej tożsamości płciowej nie jest w stanie odkryć i wypełnić zadań stojących przed nim zarówno w życiu małżeńsko-rodzinnym, jak i społeczno-zawodowym. Próba zrównania różnego typu związków jest de facto poważnym osłabieniem małżeństwa jako wspólnoty mężczyzny i kobiety oraz rodziny, na małżeństwie zbudowanej (Episkopat 2013).

W końcu wskazują, że ideologia gender jest wszechobecna:

Zdecydowana większość nie wie, czym jest ta ideologia, nie wyczuwa więc żadnego niebezpieczeństwa. Wąskie grono osób - zwłaszcza nauczycieli i wychowawców, w tym także katechetów i duszpasterzy - próbuje na własną rękę poszukiwać konstruktywnych sposobów przeciwdziałania jej. Są wreszcie i tacy, którzy widząc absurdalność tej ideologii uważają, że Polacy sami odrzucą proponowane im utopijne wizje. Tymczasem ideologia gender bez wiedzy społeczeństwa i zgody Polaków od wielu miesięcy wprowadzana jest $\mathrm{w}$ różne struktury życia społecznego: edukację, służbę zdrowia, działalność placówek kulturalno-oświatowych i organizacji pozarządowych. W przekazach części mediów jest ukazywana pozytywnie: jako przeciwdziałanie przemocy oraz dążenie do równouprawnienia (Episkopat 2013).

Potem biskupi podejmują problem dyskryminacji i jej źródeł. Dotyczy to dyskryminacji ze względu na płeć: „Kościół jednoznacznie opowiada się przeciw dyskryminacji ze względu na płeć, ale równocześnie dostrzega niebezpieczeństwo niwelowania wartości płci. To nie fakt istnienia dwóch płci jest źródłem dyskryminacji, ale brak duchowego odniesienia, ludzki egoizm i pycha, które trzeba stale przezwyciężać” (Episkopat 2013). I ze względu na seksualność: „Kościół w żaden sposób nie zgadza się na poniżanie osób o skłonnościach homoseksualnych, ale równocześnie z naciskiem podkreśla, że aktywność homoseksualna jest głęboko nieuporządkowana oraz że nie można społecznie zrównywać małżeństwa będącego wspólnotą mężczyzny i kobiety ze związkiem homoseksualnym" (Episkopat 2013).

W końcu pasterze zwracają się do katolików, by aktywnie włączyli się w przeciwdziałanie rozwojowi „ideologii gender". Wezwanie to obejmuje nie tylko osoby prywatne, lecz także instytucje znajdujące się pod kontrolą państwa:

Apelujemy także do instytucji odpowiadających za polską edukację, aby nie ulegały naciskom nielicznych, choć bardzo głośnych, środowisk, dysponujących niemałymi środkami finansowymi, które w imię nowoczesnego wychowania dokonują eksperymentów na dzieciach i młodzieży. Wzywamy instytucje oświatowe, aby zaangażowały się w promowanie integralnej wizji człowieka (Episkopat 2013).

Owe „eksperymenty” to, zdaniem pasterzy, edukacja seksualna zgodna ze standardami Światowej Organizacji Zdrowia, a także zajęcia antydyskryminacyjne prowadzone w niektórych polskich szkołach przez organizacje pozarządowe wywodzące się ze środowisk feministycznych i LGBT. 
Mimo że list biskupów brzmi bardzo ostro, w porównaniu z innym katolickimi wypowiedziami na ten temat zdaje się całkiem umiarkowany. Na przykład ksiądz dr hab. Dariusz Oko, pracownik Uniwersytetu Papieskiego Jana Pawła II w Krakowie, filozof i czołowy krytyk gender w Polsce, porównuje ideologię gender do reżimów totalitarnych XX wieku i jest przekonany, że „ideologia gender” i "homolobby” (tak nazywa ruch LGBT) są dziełem siły nieczystej. Zwraca na przykład uwagę na to, że podstawowym problemem „ideologii gender" jest jej związek $\mathrm{z}$ ateizmem. W jednym z wywiadów mówił o „postawach duchowych twórców genderideologii":

To są przede wszystkim lewaccy ateiści. Ateizm buduje na fundamentalnym, fałszywym założeniu nieistnienia Boga i przez to z konieczności błędnie rozumie człowieka i świat. (...) Ponieważ jest to błąd ogromny, ma też ogromnie złe konsekwencje. Największe błędy kulturowe i gospodarcze, a zarazem największe zbrodnie w dziejach ludzkości popełniali ateiści, a zarazem (śmiertelni) wrogowie chrześcijaństwa, którzy nigdy za to publicznie nie żałowali i nie przeprosili. Na koncie nazizmu jest ok. $50 \mathrm{mln}$ ofiar II wojny światowej, na koncie komunizmu przynajmniej $150 \mathrm{mln}$ ofiar - jako wynik wszystkich jego rewolucji, czystek i innych społecznych „eksperymentów”. (...) Ludzie, którzy są najbardziej zaciekłymi wrogami Boga, siłą rzeczy stają się też najbardziej gorliwymi sługami Szatana. Trzeba pamiętać, że to właśnie on staje się zasadniczym źródłem ich myślenia (Cichobłazińska 2013).

Czytając biskupów czy innych katolickich autorów, warto zastanowić się, dlaczego właśnie teraz polscy katolicy tak zażarcie walczą z gender. Feministki, działacze LGBT, świeccy intelektualiści i lewicowi dziennikarze proponują zwykle dwie interpretacje: zgodnie z pierwszą, najpopularniejszą, katolicy zaczęli dyskutować o gender, by odwrócić uwagę opinii publicznej od skandali pedofilskich w polskim Kościele. Na poparcie tej interpretacji można na przykład przywołać wypowiedź arcybiskupa Józefa Michalika, który otwarcie stwierdził, że „ideologia gender" jest powodem pedofilii (Stanisz 2013). Zgodnie z drugą interpretacją zainteresowanie „ideologią gender” jest reakcją Kościoła na kryzys wiary - Polacy coraz rzadziej biorą udział w katolickich rytuałach i żyją po katolicku. Badania społeczne pokazują na przykład, że jedynie mniejszość (poniżej 15\%) Polaków dotrzymuje katolickich zasad jeśli chodzi o antykoncepcję (Izdebski 2012, s. 253). Nie ma wątpliwości, że obie interpretacje zawierają ziarno prawdy, jednak w ten sposób sformułowane nie wyjaśniają wszystkiego. Chciałabym tutaj zaproponować wyjaśnienie systemowe, uwzględniające uwarunkowania zarówno globalne, jak i lokalno-historyczne.

Przede wszystkim nie możemy widzieć debaty o gender jako czegoś ograniczającego się wyłącznie do Polski. Podobne dyskusje odbywają się w niemal wszystkich krajach byłego bloku wschodniego, również tam gdzie Kościół katolicki nie jest głównym rozgrywającym (zob. Shirinian 2014; Renkin 2009, s. 20-37). Konserwatyści i nacjonaliści w całym regionie coraz bardziej interesują się tą problematyką i zachodzi między nimi wymiana myśli, często wykraczająca poza świat postsocjalistyczny. Podobne debaty od jakiegoś czasu prowadzane są m.in. w Stanach Zjednoczonych, Niemczech czy Francji i, jak pokazała Elżbieta Korol- 
czuk, współkształtują one naszą krajową sytuację (Korolczuk 2014, s. 3; Herzog 2008). W Polsce dostępne są przekłady sztandarowych publikacji antygenderowych, np. Rewolucja genderowa. Nowa ideologia seksualności, autorstwa niemieckiej socjolog Gabriele Kuby, która ukazała się już w 2007 roku; młodzieżowe pismo katolickie „Miłujcie Się!” od lat zapoznaje czytelników z zachodnim, konserwatywnym podejściem do przemian w obrębie ról płciowych i seksualności'; z kolei polscy krytycy zadbali, by usłyszano ich na świecie - List pasterski na Niedziele Świętej Rodziny 2013 roku jest jedynym tego typu dokumentem, który znajdziemy na oficjalnej stronie episkopatu w wersji angielskiej.

Jednak powiedzenie, że histeria genderowa w Polsce to jedynie element globalnej paniki nie odpowiada na pytanie, jak to się stało, że w Polsce właśnie teraz ta kwestie wybuchła - przecież książka Kuby była dostępna po polsku już w 2007 roku, a w 2006 roku na łamach „Miłujcie Się!” nazywano ruch LGBT „nową formą totalitaryzmu” (Bilewicz 2006, s. 45-48), podobne zestawienia czyni się obecnie w odniesieniu do „ideologii gender” (która zawiera w sobie, jak widzieliśmy, kwestię praw osób LGBT), co widać na przykład w cytowanym powyżej wywiadzie z ks. Oko.

Kontekst lokalny uwzględnia w analizie paniki wokół gender Magdalena Grabowska i wskazuje na nie tylko globalne, lecz także historyczne korzenie dzisiejszej sytuacji, którą określa mianem backlashu (Grabowska 2014). Odwołując się do prac m.in. Małgorzaty Fidelis i Shany Penn, dowodzi, że Gomułkowska polska droga do socjalizmu, a następnie transformacja ustrojowa przyczyniły się do dominacji Kościoła katolickiego we współczesnej polskiej sferze publicznej (Grabowska 2014, s. 8-9).

Trudno nie zgodzić się z Korolczuk i z Grabowską. Jednak, moim zdaniem, w tej lokalno-globalnej układance brakuje jeszcze jednego elementu. Debata na temat gender jest w mojej opinii częścią większej walki o to, co naukowcy społeczni nazywają obywatelstwem kulturowym ${ }^{5}$. Jest ono czymś więcej niż posiadaniem paszportu danego kraju, czymś więcej niż zbiorem praw i obowiązków obywatela. Dotyczy poczucia przynależności i tożsamości. Zatem, kto jest prawdziwym Polakiem? Czy feministki, geje bądź osoby trans albo mężczyźni lub kobiety, który nie trzymają się wzoru tradycyjnych ról płciowych, mogą w pełni należeć do narodu polskiego? Czy geje, lesbijki i feministki mogą identyfikować się jako prawdziwi/we Polacy/ki? Czy mogą nazywać się polskimi patriotami/kami? Czy mogą być bohaterami/kami narodowymi?

Dzisiejsza debata na temat obywatelstwa kulturowego zaczyna się w okolicach 1989 roku. Upadek komunizmu rozpoczął walkę wokół płci i seksualności. W Polsce, tak jak w innych państwach regionu, początek lat 90. XX wieku wyznacza istotną zmianę, przejście od gospodarki regulowanej przez państwo do wolnego rynku, od socjalizmu do neoliberalizmu, od reżimu totalitarnego do

4 Porównaj przykładowo: (Oko 2009, s. 40-43; omówienie Kościańska 2012a, s. 145-146; 2013, s. 427-439).

5 O obywatelstwie w kontekście płci i seksualności więcej w: (Lister 2002, s. 191-208; Renkin 2012, s. 367-382; Rofel 2012, s. 412-435). 
demokracji. Po latach walki Polacy mogli wreszcie swobodnie wyrażać swoje przekonania. Jaka była pierwsza wielka debata publiczna w Polsce? Czy dotyczyła gospodarki? Czy chodziło o państwo? O Kościół? Nie - to była aborcja. W czasach komunistycznych w Polsce, tak jak w innych krajach Europy Środkowej, aborcja była legalna i łatwo dostępna. Debata początku lat 90. na temat aborcji dotyczyła $\mathrm{w}$ dużym stopniu roli kobiet. Czy mogą robić karierę poza gospodarstwem domowym czy powinny się raczej skoncentrować na rodzeniu dzieci? Kościół, ważny aktor owej debaty, argumentował, że polskie kobiety powinny poświęcić się odbudowywaniu narodu polskiego po socjalizmie, aborcje postrzegano jako zagrożenie dla narodu (zmniejszała liczbę Polaków). Gorąca debata zakończyła się niemal całkowitym zakazem aborcji wprowadzonym w 1993 roku $^{6}$. Owa dyskusja nie była jedyną $w$ tym czasie, a zakaz aborcji nie jest jedyną zmianą w polskim prawie, która zaszła w czasie transformacji i dotyczyła płci i seksualności. Operacje zmiany płci i terapia psychologiczna, która im towarzyszy, były w pełni opłacane przez państwo - od lat 90. pacjent musi płacić za nie sam. Procedura prawna zmiany płci była w PRL dosyć zbiurokratyzowana i nieprzyjemna, ale od 1989 roku stała się bardziej skomplikowana i wymaga procesu sądowego przeciwko jednemu z rodziców (Dębińska 2013, s. 221-224). Antykoncepcja i zapłodnienie in vitro były subsydiowane przez państwo ${ }^{7}$. To również zmieniono we wczesnych latach 90. Poza debatą aborcyjną w 1993 roku, początek lat 90. był czasem innych publicznych dyskusji o płci i seksualności, na przykład o masturbacji, w ramach której intelektualiści katoliccy twierdzili, że seks w pojedynkę stanowi zagrożenie dla narodu polskiego, podczas gdy druga strona opowiadała się za większą różnorodnością seksualną (Kościańska 2012b). Lata 90. to też czas pracy nad konstytucją. Jak przypomniała niedawno politolożka Solongo Wandan (2004, s. 171-181), żywo dyskutowano wtedy nad wprowadzeniem do konstytucji zakazu dyskryminacji ze względu na orientację seksualną. Koniec końców nie został wprowadzony, do czego przyczynił się Kościół katolicki. Tematy takie jak aborcja i in vitro wielokrotnie powracały jako tematy gorących dyskusji. Za każdym razem Kościół wykorzystywał płeć i seksualność, by wzmocnić swą pozycję.

Jednocześnie okres od początku lat 90. do dziś to czas formowania się i coraz większej widzialności prężnie rozwijających się ruchów feministycznych i LGBT. W ostatnich latach aktywiści i aktywistki domagają się nie tylko praw, lecz także obywatelstwa w sensie kulturowym, czyli możliwości przynależności do wspólnoty narodowej. My też jesteśmy Polakami, my też tworzymy wspólnotę narodową - można było wyczytać z marszów i parad, gdzie polskie flagi pojawiały się razem z tęczowymi lub powiewały nad Manifami. Agnieszka Graff, jedna z najbardziej rozpoznawalnych postaci polskiego feminizmu, otwarcie stwierdziła na łamach "Gazety Wyborczej”, że jest patriotką i że warto o polskość zawalczyć $\mathrm{z}$ konserwatystami. W Adersonowskim duchu pisała:

6 Debata aborcyjna z tego czasu doczekała się wielu analiz, zob. m.in. (Graff 2001; Szpakowska 2003).

Od tego czasu zapłodnienie in vitro stało się tematem gorących dyskusji. Zob. (Radkowska-Walkowicz 2012, s. 30-37; 2013). 
Kategoria narodowości pozostaje jednym z kluczowych elementów nowoczesnej wrażliwości, głównym wyznacznikiem zbiorowej tożsamości, systemem organizującym naszą orientację w świecie. (...) Narodowości bywają jednak „wyobrażone” na rozmaitych zasadach - jako wspólnota krwi, jako oblężona twierdza, jako wspólna misja do wypełnienia - i te zasady podlegają negocjacjom. Otóż w Polsce toczy się dziś spór o to, czy naszą ojczyznę będziemy sobie „wyobrażać” pod dyktando endeków, czy też wedle innych, bardziej otwartych i demokratycznych reguł. Stawka jest znaczna (Graff 2007).

Realizacją jej postulatów są stwierdzenia feministycznych i qeerowych historyków/czek i literaturoznawców/czyń, zgodnie z którymi ważne postaci polskiej literatury i historii wykraczały poza tradycyjne role płciowe i tożsamości seksualne. Na przykład Krzysztof Tomasik opowiedział historie polskich pisarzy i pisarek, którzy wykraczali poza ramy heteronormatywności. Maria Konopnicka, autorka jednej z najważniejszych polskich pieśni patriotycznych Roty, opisana została jako partnerka Marii Dulębianki, jednej z pierwszych polskich feministek (Tomasik 2008; Renkin 2009). Obie zostały też patronkami podyplomowych gender studies w Instytucie Badań Literackich PAN. W pracy Elżbiety Janickiej bohaterowie mitotwórczej powieści Aleksandra Kamińskiego Kamienie na szaniec zostali przedstawieni jako nieheteronormatywni, co stało się przedmiotem ogólnopolskiej dyskusji i powodem oburzenia środowisk konserwatywnych (Pazeda 2013). Wszystkie te zabiegi mają na celu budowę nowego modelu Polaka i Polki, wykraczającego poza zbitkę Polak-katolik, przywiązanie do „tradycyjnej” rodziny i "tradycyjnych" ról płciowych, a także wpisanie nienormatywności w historię Polski, w szczególności jej najważniejsze, tożsamościotwórcze momenty, takie jak XIX-wieczna walka z zaborcą i ruch oporu w czasie II wojny światowej. Chodzi więc o przedefiniowanie polskiego obywatelstwa kulturowego. Jeśli debatę na temat „ideologii gender” umieścimy w tym kontekście, jasne staje się, że jest ona odpowiedzią na coraz intensywniejsze działania feministek i aktywistów/ek LGBT, chcących na nowo opowiedzieć historię Polski i zbudować nową polską tożsamość narodową. Jest ona kontynuacją wcześniejszych dyskusji na temat obywatelstwa kulturowego (tych toczących się przy okazji aborcji, in vitro, orientacji seksualnej w konstytucji czy masturbacji), które spowodowały, że coraz częściej polska tożsamość narodowa definiowana jest jako różnorodna i niekoniecznie katolicka, a Polacy niekoniecznie żyją na katolicką czy konserwatywną modłę.

Od początku lat 90. wielu analityków twierdziło, że debata aborcyjna 1993 roku, a także inne dyskusje na temat seksualności i płci są jedynie tematami zastępczymi, prowadzonymi, by odwrócić uwagę od zagadnień ważnych, takich jak gospodarka. Na przykład Marcin Król, filozof i działacz opozycji antykomunistycznej, w skądinąd niezwykle ciekawym wywiadzie dla "Gazety Wyborczej”, krytykuje polskie elity za zwracanie zbyt wielkiej uwagi na płeć, moralność i dyskryminację ze względu na płeć i seksualność; twierdzi, że powoduje to odwrócenie uwagi od nierówności społecznych i ekonomicznych, a w konsekwencji rozrost prawicy. Sprawę potraktował dość dosadnie: 
Wszystkie debaty, które nas obecnie rozpalają, kręcą się wokół - za przeproszeniem dupy i okolic. Dotyczą kwestii związanych z moralnością seksualną. A to nie jest centrum społecznego życia łącznie z taką poważną sprawą jak aborcja. Postępowe elity zajęły się nierównościami płciowymi i seksualnymi, a zupełnie straciły z oczu proste nierówności ekonomiczne, które są skandalem. Bo co się będziemy zajmować jakimiś XIX-wiecznymi kategoriami społecznymi, mamy nowsze, ciekawsze. Zwykłych ludzi z ich zwykłymi problemami oddaliśmy w ten sposób na pastwę zidiociałej prawicy, która obieca im wszystko (Sroczyński 2014).

Jeśli jednak spojrzymy na te debaty przez pryzmat kategorii obywatelstwa kulturowego, zobaczymy, że seksualność i płeć są rdzeniem tożsamości narodowej i nacjonalizmu (zob. Mosse 1985; Graff 2008). Przynależność do wspólnoty narodowej i zyskiwanie obywatelstwa kulturowego zależy od właściwych zachowań i tożsamości seksualnych i płciowych (co w rezultacie przekłada się na kwestie ekonomiczne w postaci chociażby Foucaultowskiej biopolityki populacji) (Foucault 1995). Kościół i aktywiści/stki feministyczni/e/LGBT mają różne poglądy na polską tożsamość narodową. Walka trwa. Szybkie spojrzenie na dzisiejszą polską debatę publiczną, w obrębie której feministki muszą tłumaczyć, że feminizm nie powoduje pedofilii, jak twierdzi Kościół, prowadzić może do konkluzji, że to właśnie Kościół - wykorzystujący swoją ukształtowaną historycznie silną pozycję, wzmocniony argumentami wypracowanymi przez antygenderową międzynarodówkę - wygrywa. Ale głębsza analiza stylu życia i przekonań Polaków pokazuje, że nie są oni tak bardzo katoliccy (Borowik, Doktór 2001; Izdebski 2012) i ideały równościowe są im coraz bliższe - to przecież Polska jest jedynym obecnie krajem na świecie, gdzie trans kobieta zasiadała w parlamencie; to tu czołowa feministka była wicemarszałkinią Sejmu, a niekryjący się ze swoją orientacją gej pokonał w wyborach samorządowych polityczny establishment - a Kościół i konserwatyści znów wykorzystują płeć i seksualność do walki politycznej, obrony własnych interesów i kształtowania określonej wizji narodu.

\section{Literatura:}

Bilewicz J., 2006, O wolności, równości, tolerancji, Sodomie i Godomie, „Miłujcie Się!” nr 2.

Borowik I., Doktór T., 2001, Pluralizm religijny i moralny w Polsce. Raport z badań, Zakład Wydawniczy "Nomos”, Kraków.

Cichobłazińska A., 2013, Gender - ideologia totalna (wywiad z ojcem Dariuszem Oko), http://www.niedziela.pl/artykul/106423/nd/.

Dębińska M., 2013, Natura, kultura i hybrydy. Prawne konstrukcje transseksualizmu , „Lud”, t. 97.

Grabowka M., 2014, Cultural war or "business as usual"? Recent instances, and the historical origins, of a "backlash" against women's and sexual rights in Poland, http://pl.boell.org/sites/default/files/uploads/2014/10/cultural_war_or_grabowska.pdf [dostęp: 26.12.2014].

Foucault M., 1995, Historia seksualności, przeł. B. Banasiak, T. Komendant i K. Matuszewski, Czytelnik, Warszawa.

Graff A., 2001, Świat bez kobiet. Płeć w polskim życiu publicznym, W.A.B., Warszawa. 
Graff A., 2007, polskość nie jest wtasnością endeków, „Gazeta Wyborcza”, 23.08.2007, s. 16. Też na http://www.krytykapolityczna.pl/TekstypozaKP/GraffPolskoscniejestwlasnosciaen dekow/menuid-76.html [dostęp: 28.12.2014].

Graff A., 2008, Rykoszetem. Rzecz o ptci, seksualności i narodzie, W.A.B., Warszawa.

Herzog D., 2008, Sex in Crisis: The New Sexual Revolution and the Future of American Politics, Basic Books, New York.

Izdebski Z., 2012, Seksualność Polaków na początku XXI wieku. Studium badawcze, Wydawnictwo Uniwersytetu Jagiellońskiego, Kraków.

Korolczuk E., 2014, "The War on Gender" from a Transnational Perspective - Lessons for Feminist Strategising, s. 3, http://pl.boell.org/sites/default/files/uploads/2014/10/war_on_gender_ korolczuk.pdf [dostęp: 24.12.2014].

Kościańska A., 2012a, Kościoty i związki wyznaniowe w Polsce wobec osób LGBT, w: Sytuacja społeczna osób LGBT. Raport za lata 2010-2011, red. M. Makuchowska i M. Pawlęga, http://www.kph.org.pl/publikacje/Raport_badania_LGBT_do_netu.pdf [dostęp: 28.12.2014].

Kościańska A., 2012b, Czy onanista to też Polak? Debata o masturbacji 1993-1994, „InterAlia”, no. 7, http://www.interalia.org.pl/pl/artykuly/aktualny_numer_2012_7/12_czy_onanista_to_tez_polak_debata_o_masturbacji_19931994.htm [dostęp: 26.12.2014].

Kościańska A., 2013, Jak uchronić polskie dzieci przed demoralizacją? Dyskurs medycyny i psychologii w pewnym młodzieżowym piśmie katolickim, w: Etnograficzne wędrówki po obszarach antropologii. Tom w darze dla Profesora Lecha Mroza, red. Ł. Smyrski, K. Waszczyńska, Wydawnictwo DiG, Warszawa.

Kuby G., 2007, Rewolucja genderowa. Nowa ideologia seksualności, przeł. M. Urban, D. Jankowska, Wydawnictwo Homo Dei, Kraków.

List pasterski na Niedzielę Świętej Rodziny 2013 roku, http://episkopat.pl/dokumenty/listy_pasterskie/5545.1,List_pasterski_na_Niedziele_Swietej_Rodziny_2013_roku.html [dostęp: 24.12.2014].

Lister R., 2002, Sexual Citizenship [w:] Handbook of Citizenship Studies, E.F. Isin, B.S. Turner (ed.), SAGE Publications: London. Thousand Oaks, New Delhi.

Mosse G.L., 1985, Nationalism and Sexuality. Respectability and Abnormal Sexuality in Modern Europe, Fertig, New York.

D. Oko, 2009, Kościót wobec homoideologii, „Miłujcie Się!”, nr 1.

Pezda A., 2014, Byli żotnierze Szarych Szeregów zszokowani wywiadem na temat „Kamieni na szaniec", "Gazeta Wyborcza", http://wyborcza.pl/1,76842,13679057,Byli_zolnierze_Szarych_Szeregow_zszokowani_wywiadem.html [dostęp: 28.12.2014].

Radkowska-Walkowicz M., 2012, The creation of 'monsters': the discourse of opposition to in vitro fertilization in Poland, "Reproductive Health Matters”, t. 20, nr 40.

Radkowska-Walkowicz M., 2013, Doświadczenie in vitro. Niepłodność i nowe technologie reprodukcyjne w perspektywie antropologicznej, Wydawnictwa Uniwersytetu Warszawskiego, Warszawa.

Renkin H., 2009, Homophobia and Queer Belonging in Hungary, „Focaal - European Journal of Anthropology" No. 53.

Renkin H.Z., 2012, Przodkinie i pielgrzymki. Tworzenie lesbijskiej historii i przynależność na postsocjalistycznych Wegrzech [w:] Antropologia seksualności. Teoria, etnografia, zastosowanie, przeł. M. Petryk, red. A. Kościańska, Wydawnictwa Uniwersytetu Warszawskiego, Warszawa. 
Rofel L., 2012, Jakość pożądania. Wyobrażanie tożsamości gejowskich w Chinach [w:] Antropologia seksualności. Teoria, etnografia, zastosowanie, przeł. M. Petryk, red. A. Kościańska, Wydawnictwa Uniwersytetu Warszawskiego, Warszawa.

Shirinian T., 2014, Gender hysteria: the dangers of the emigration of the family and the immigration of homosexuality in post-Soviet Armenia, referat wygłoszony w ramach sesji Innovation and continuity in the anthropology of gender and sexuality na zjeździe European Association of Social Anthropologists, Tallinn, 31.07-3.08.2014.

Sroczyński G., 2014, Byliśmy głupi, wywiad z Marcinem Królem, http://wyborcza.pl/magazyn/1,136528,15414610,Bylismy_glupi.html?piano_d=1 [dostęp: 26.12.2014].

Stanisz B., 2013, Winni rodzice, feministki i... Abp Michalik znów o pedofilii, http://wroclaw.gazeta.pl/wroclaw/1,35771,14788274,Winni_rodzice_feministki_i__Abp_Michalik_znow o.html.

Szpakowska M., 2003, Chcieć i mieć. Samowiedza obyczajowa w Polsce czasu przemian, W.A.B., Warszawa.

Tomasik K., 2008, Homobiografie. Pisarki i pisarze polscy XIX i XX wieku, Wydawnictwo Krytyki Politycznej, Warszawa.

Vance C., 2007, Konstruktywizm społeczny: kłopoty z historiq seksualności, przeł. A. Kościańska, [w:] Gender. Perspektywa antropologiczna, t. 2, Kobiecość, męskość, seksualność, R.E. Hryciuk, A. Kościańska (red.), Wydawnictwa Uniwersytetu Warszawskiego, Warszawa.

Wandan S., 2004, Making New Rights: Constitutional Agenda-Setting in the Transitions of Poland (1989-1997) and South Africa (1990-1994 (1996)). Rozprawa doktorska Graduate Faculty of Political and Social Science of the New School.

\section{Summary}

\section{Gender panic: substitution matter or conflict over cultural citizenship}

The article explores gender discourses that circulate in the media, popular culture and the catholic church in Poland, and how this relates to policy and practice, ultimately shaping the sexual politics. It explores what cultural citizenship is, what sexual politics are and why the idea of moral panic provides a useful analytical lens for looking at current debates around gender, sexuality, education and social role of the religion in Poland.

Keywords

gender, catholic church, ideology, culture, citizenship

\section{Słowa kluczowe}

gender, kościół katolicki, ideologia, kultura, obywatelstwo 